\begin{tabular}{ccc}
\hline International Journal of Engineering \& Technology, $7(4.30)(2018)$ 109-111 \\
SPC \\
Website www.sciencepubco.com/index.php/IJET \\
Research paper
\end{tabular}

\title{
Assessment and Potential of Carbon Storage Capacity of Species of Herbaceous Plants in Universiti Tun Hussein Onn Malaysia, Main Campus, Batu Pahat, Johor Malaysia
}

\author{
Yunusa Audu ${ }^{1 * 2}$, Alona C. Linatoc ${ }^{2}$, Aisha $I^{2,3}$ \\ ${ }^{1 *}$ Department of Biological Science, Faculty of Natural Science, Ibrahim Badamasi Babangida University Lapai, \\ Niger State, PMB 11 Nigeria \\ ${ }^{2}$ Department of Technology and Natural Resources, Faculty of Applied Sciences and Technology, Universiti Tun Hussein Onn Malaysia, \\ Pagoh Campus, Pagoh Educational Hub, Km.1 Jalan Panchor, 84600 Muar, Johor, Malaysia \\ 3Department Department of Biological Science, Faculty of Science, Federal University Dutse, Jigawa State, PMB 7156 Nigeria. \\ *Corresponding author E-mail: abduldaudu@yahoo.co.uk
}

\begin{abstract}
Carbon dioxide $\mathrm{CO}_{2}$ is an important trace gas in earth's atmosphere. It is a greenhouse gas that plays a vital role in regulating the earth's surface temperature through the greenhouse effect. Increase beyond the ambient concentration leads to global warming. Increase in $\mathrm{CO}_{2}$ discharge in UTHM (238.9 ha), due to increase in a number of vehicles; other greenhouse gases released from building amenities and dis-charges from neighbouring industries appeals for attention. Study was conducted on seven common species of herbaceous plants for their capacity in sequestering $\mathrm{CO}_{2}$. Estimation of carbon storage of herbaceous plants was obtained by the assessments of the aboveground standing biomass and their photosynthetic capacity. Musa sp has the highest $\mathrm{CO}_{2}$ absorption of $12.2 \mu \mathrm{mol} \mathrm{m} \mathrm{m}^{-2} \mathrm{~s}^{-1}$, followed by Heliconia. psittacorum $\left(10.63 \mu \mathrm{mol} \mathrm{m} \mathrm{m}^{-2} \mathrm{~s}^{-1}\right)$. Euphorbia tithymaloides and Costus spicatus has the lowest absorption with 3.63 and 3.76 $\mu \mathrm{mol} \mathrm{m} \mathrm{m}^{-2} \mathrm{~s}^{-1}$ respectively. Calathea lutea and Hymenocallis latifolia shared the highest biomass accumulation of $0.04 \mathrm{~kg}$. These were followed by E. tithymaloides and Alpinia purpurata with $0.02 \mathrm{~kg}$. The least biomass of $0.01 \mathrm{~kg}$ was accumulated by $H$. psittacorum and C. spicatus. The total standing biomass captured by all the species of herbaceous plants is $0.13 \mathrm{~kg}$. Therefore, species of herbaceous plants in UTHM have the potentials to absorb an adequate amount of $\mathrm{CO}_{2}$ from the atmosphere thereby contributing to reducing-the effects of localized global warming.
\end{abstract}

Keywords: Absorption of Carbon; Carbon Dioxide; Global Warming; Greenhouse Effect; Herbaceous Plants.

\section{Introduction}

Urban forests and trees are receiving added significance in developing countries of the world. They remain vital tools in urban biodiversity and play a role in reducing worldwide warming. Universiti Tun Hussein Onn Malaysia UTHM is an institution of higher learning located at Parit Raja, Batu Pahat in the state of Johor, Malaysia with coordinates $1.8531^{\circ} \mathrm{N}, 103.0864^{\circ}$, occupying area of 238.8964 ha. The University is furnished with state of the art research facilities, Professional human resources and coordinated transport system aimed at creating conducive leaning environment.

There are about 11,403 registered cars as at 21/2/2018 (UTHM, 2018). The higher number of vehicles running within the campus causes the increase in the discharge of additional $\mathrm{CO}_{2}$ and other green gases from within the campus; this leads to a higher emission of gases into the University, which will eventually influence the local microclimate. Report from UTHM carbon emission (1) shows that more than 20,000 tons of carbon are emitted into the environment every year.

The worldwide environmental warming is increasing yearly. The continuous increase of $\mathrm{CO}_{2}$ in the atmosphere that as witnessed from 280 parts per million (ppm) in 1850 up to $394 \mathrm{ppm}$ in 2012 and recently 410.76 is as a result of continues accumulation of
$\mathrm{CO}_{2}$ in the environment (10). The occurrence persisted to as much as $400 \mathrm{ppm}$ of $\mathrm{CO}_{2}$ concentration in the surroundings doubling as large as it is compared to the last 1800yrs (6).

The United Nation Framework Conference on Climate Change (UNFCCC), at its 16th Conference of the Paris agreement held in 2010, parties agreed that future global warming should not exceed $2{ }^{\circ} \mathrm{C}$ and limit temperature to $1.5^{\circ} \mathrm{C}$ compared to the pre-industrial temperature level as a result of the accumulation of $\mathrm{CO}_{2}$ in the environment (8).

\section{Roles of Species of Herbaceous Plants in Carbon Storage Capacity}

The constant increase of $\mathrm{CO}_{2}$ in the environment triggers an increase in the amount of carbon in the atmosphere; this ultimately interrupts the worldwide carbon cycle. Nevertheless, the effect is frequently reduced as plants function naturally to accumulate and store the carbon into biomass on maturity.

A reported by (9) postulated the average aboveground standing stocks of carbon range from 16 to $36 \mathrm{Mg} \mathrm{ha}^{-1}$, whereas small home gardens have greater carbon stocks on a unit area basis than huge and medium-sized ones. This indicates the potential for carbon sequestration and agro-biodiversity preservation, mainly by small household gardens. 
A report by (2) indicated the biomass accumulation of Abaca (Musa textilis Nee), fresh weight of the pseudostem of the sample plants to range from $1.6 \mathrm{~kg}$ to $35.3 \mathrm{~kg}$ while that of the leaf tissues ranged from $0.7 \mathrm{~kg}$ to $6.4 \mathrm{~kg}$. These values, when summed-up, gave the above-ground fresh weight that ranged from $2.3 \mathrm{~kg}$ to $41.7 \mathrm{~kg}$. Moisture contents are from $78.5 \%$ and $90.9 \%$. Likewise pseudostem dry weight range from $0.1 \mathrm{~kg}-3.8 \mathrm{~kg}$ while the leaf dry weight alternate from $0.10 \mathrm{~kg}-1.4 \mathrm{~kg}$.

Thus, the total above-ground dry weight ranged from $0.3 \mathrm{~kg}$ to 5.0 $\mathrm{kg}$ only for all the collected samples. It is reported that the bulk of the above-ground biomass was mainly attributed to the high biomass content of the pseudostem tissues and not of the leaf tissues. A report by (3) indicated that Saccharum officinarum had maximum carbon mitigation with 3.3 ton of carbon $\mathrm{ha}^{-1}$ which is followed by Oryza sativa with 0.6 ton of carbon $\mathrm{ha}^{-1}$ and Musa paradisiacal 0.3 ton of carbon ha-1 in annual crops. However, agroforestry land use systems viz. O. sativa, $S$. officinarum and $M$. paradisiacal boundary plantation contributed 8.0, 5.4 and 5 ton of carbon $\mathrm{ha}^{-1}$ respectively, in non-destructive approach for biomass estimation and carbon mitigation in different land use systems.

\section{Methodology}

The study was carried out at UTHM main campus with coordinate $1.8531^{\circ} \mathrm{N}, 103.0864$, with 11,403 cars recorded as at $21 / 2 / 2018$. The overall area covered by the campus is 238.9 hectares out of which 152.7 acres are developed, and the remaining space is reserved for future development. The species of herbaceous plants within UTHM main campus were surveyed and identified as described by (7). Substantial numbers of varieties and wellpreserved samples collected were deposited at UTHM repository for further research reference.

The species were studied for quantification of $\mathrm{CO}_{2}$ sequestration through the measurement of $\mathrm{CO}_{2}$ absorption capacity. Li-6400 Portable Photosynthesis System (LI-COR Nebraska Inc., USA) was used to measure the $\mathrm{CO}_{2}$ photosynthetic assimilation rate (PASR).

For a reasonable estimation of $\mathrm{CO}_{2}$ and to avoid uncertainty during measurement, the Li-6400 air flow was set at $500 \mu \mathrm{mol}, \mathrm{CO}_{2}$ at $360 \mu \mathrm{mol}$, block temperature $300 \mathrm{oC}$ and PAR (Photosynthetic active radiation) light at $1000 \mu \mathrm{mol} / \mathrm{m}^{-2} / \mathrm{s}^{-2}$. Data was analysis using one-way ANOVA, t-Test, and Levene test for homogeneity of variance. For post-hoc comparison of means between different levels of the photon, Turkey's HSD test was used. All the statistical analyses were conducted using Excel and IBM SPSS Statistics 22. Biomass accumulation of carbon by the species was estimated through the use of Excel to compare the means of the species. The below procedure was followed to determine the biomass of the species.

\subsection{Measurement of Plant height and diameter}

A non-destructive method was used to estimate the biomass of herbaceous species. The diameter and height of plants were measured directly by the measuring tape. The measurement of diameter was made at about $5.0 \mathrm{~cm}$ from ground level.
Table 1: A checklist of species of herbaceous plants showing introduced, native and their total number

\begin{tabular}{|c|c|c|c|c|}
\hline Serial/Number & $\begin{array}{c}\text { Species of } \\
\text { plant }\end{array}$ & Introduced & Native & Total NO \\
\hline 1 & $\begin{array}{l}\text { Alpinia pur- } \\
\text { purata }\end{array}$ & $\sqrt{ }$ & & 1437 \\
\hline 2 & $\begin{array}{c}\text { Calathea } \\
\text { lutea }\end{array}$ & $\sqrt{ }$ & & 1827 \\
\hline 3 & $\begin{array}{c}\text { Costus } \\
\text { spicatus }\end{array}$ & & $\sqrt{ }$ & 14,648 \\
\hline 4 & $\begin{array}{c}\text { Euphorbia } \\
\text { tithymaloides }\end{array}$ & $\sqrt{ }$ & & 153 \\
\hline 5 & $\begin{array}{c}\text { Heliconia } \\
\text { psittacorum }\end{array}$ & $\sqrt{ }$ & & 78 \\
\hline 6 & $\begin{array}{c}\text { Hymenocallis } \\
\text { latifolia }\end{array}$ & $\sqrt{ }$ & & 2632 \\
\hline 7 & Musa sp & $\sqrt{ }$ & & 356 \\
\hline $\mathrm{T} / \mathrm{NO}$ & & & & 21,172 \\
\hline
\end{tabular}

\subsection{Total Standing Biomass (TSB) of herbaceous plants.}

The equation $\mathrm{Y}=0.11574+0.9449 \mathrm{D} 2 \mathrm{H}$ by (4) was used to estimate the biomass of herbaceous plants. Where $\mathrm{D}$ is diameter at breast height and $\mathrm{H}$ is the height of the plants.

\subsection{Below ground biomass (BGB) and leaf carbon con tent determination}

The Below Ground Biomass (BGB) includes all biomass of live roots excluding fine roots less than $2 \mathrm{~mm}$ in diameter. The belowground biomass was calculated by multiplying total standing biomass (TSB) by 0.26 factors as the root: shoot ratio (TSB Kg/ Herbaceous plants x $0.26(5)$.

However, leaves carbon content (LCC) was obtained by the leaf ashing method as described by (11) and the resulting ash content was used to determine the leaves carbon content (LCC) of the studied plants.

Species of herbaceous plants play a role in $\mathrm{CO}_{2}$ absorption thereby in their capacity function to reduce the effect of localized global warming.

\section{Result}

There are twenty-two thousand one hundred and seventy-two individual species of herbaceous plants (Table 1 above). C. spicatus has the largest number of species with 14,689, while $H$. psittacorum has the lowest number of 78. The result in Table 2 indicates that $C$. lutea and $H$. latifolia had the highest biomass accumulation of $0.04 \mathrm{~kg}$, which was the highest when compared to other species of herbaceous plants that are comparable.

The total standing biomass captured by all the species is $0.1 \mathrm{~kg}$ of $\mathrm{CO}_{2}$ (Table 2). The $\mathrm{CO}_{2}$ absorption of the species studied is shown in Table 2, Figure 2. Musa sp has the highest $\mathrm{CO}_{2}$ absorption of $12.2 \mu \mathrm{mol} \mathrm{m}^{-2} \mathrm{~s}^{-1}$, followed by $H$. psittacorum with 10.6 $\mu \mathrm{mol} \mathrm{m} \mathrm{m}^{-2} \mathrm{~s}^{-1}$ and A. purpurata with $8.9 \mu \mathrm{mol} \mathrm{m} \mathrm{m}^{-2} \mathrm{~s}^{-1}$. E. tithymaloides and $C$. spicatus had the lowest absorption of 3.6 and 3.8 $\mu \mathrm{mol} \mathrm{m} \mathrm{m}^{-2} \mathrm{~s}^{-1}$ respectively. However, the overall total $\mathrm{CO}_{2}$ absorption for all the species is $52.1 \mu \mathrm{mol} \mathrm{m} \mathrm{m}^{-2} \mathrm{~s}^{-1}$ (Table2).

Table 2: Showing the quantity of biomass accumulation of common herbaceous plants with $\mathrm{CO}_{2}$ absorption capacity. S/F-Species Factor, TSB-Total Standing Biomass and LCC-Leaf Carbon Content.

\begin{tabular}{|c|c|c|c|c|c|c|c|c|}
\hline Serial/Number & Species Scientific name & Height & Diameter & Number of species & $\begin{array}{l}\mathrm{CO}_{2} \text { Absorption }\left(\mu \mathrm{mole} / \mathrm{m}^{-2} / \mathrm{s}^{-}\right. \\
\left.{ }^{1}\right)\end{array}$ & $\mathrm{S} / \mathrm{F}$ & LCC (kg) & $\begin{array}{l}\text { TSB } \\
(\mathrm{kg})\end{array}$ \\
\hline 1 & H. psittacorum & 12.87 & 0.18 & 78 & $10.6 \pm 1.05$ & 0.2 & 0.01 & 0.01 \\
\hline 2 & E. tithymaloides & 11.50 & 0.11 & 153 & $4.5 \pm 4.81$ & 0.2 & 0.02 & 0.01 \\
\hline 3 & A. purpurata & 6.04 & 0.20 & 1437 & $8.9 \pm 1.04$ & 0.2 & 0.01 & 0.01 \\
\hline 4 & Musa sp & 2.46 & 0.11 & 356 & $12.2 \pm 0.46$ & 0.01 & 0.01 & 0.01 \\
\hline
\end{tabular}




\begin{tabular}{|l|l|l|l|l|l|l|l|l|}
\hline 5 & C. lutea & 9.0 & 0.18 & 1827 & $7.2 \pm 2.11$ & 0.04 \\
\hline 6 & H. latifolia & 8.67 & 0.8 & 2632 & $4.9 \pm 1.65$ & 0.04 \\
\hline 7 & C. spicatus & 7.22 & 0.2 & 14689 & $3.8 \pm 0.77$ & 0.04 \\
\hline T/NO & & & & 21,172 & 0.07 & 0.01 \\
& & & & 52.1 & 0.01 \\
\hline
\end{tabular}

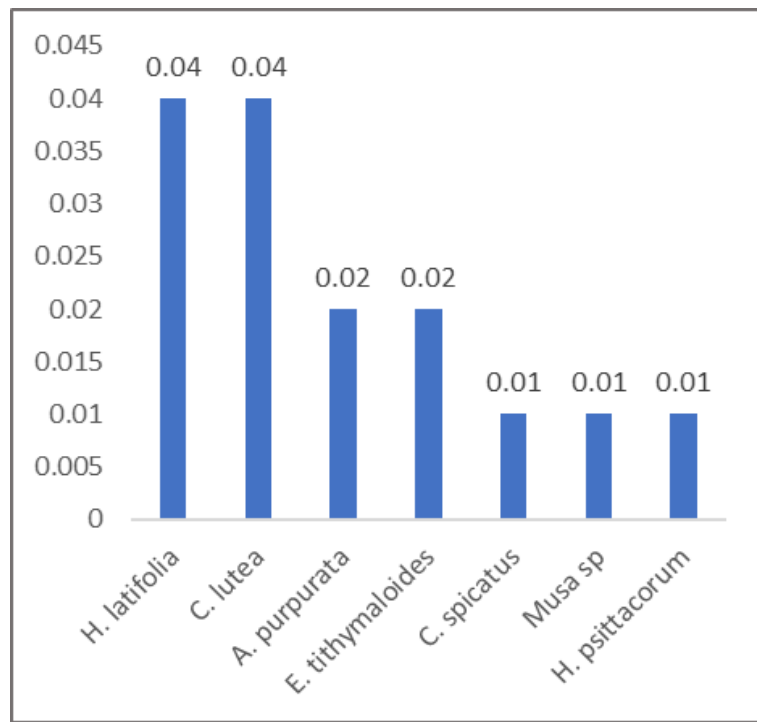

Fig. 1: Graph showing total standing biomass accumulation of her herbaceous plants

However, species of herbaceous plants in our environment play a role in the reduction of atmospheric carbon dioxide level. Even though their accumulation of carbon is not in tons, they still store a reasonable quantity. From the result gotten, it could be concluded that $\mathrm{CO}_{2}$ absorption and sequestration determined for common herbaceous species shows that, $C$. lutea and $H$. latifolia has a higher $\mathrm{CO}_{2}$ sequestration rate of $0.04 \mathrm{~kg}$ than the other species with lower sequestration rate. Musa sp was found to have the highest $\mathrm{CO}_{2}$ absorption of $12.2 \mu \mathrm{mol} \mathrm{m} \mathrm{m}^{-2} \mathrm{~s}^{-1}$ when compared with other species studied.

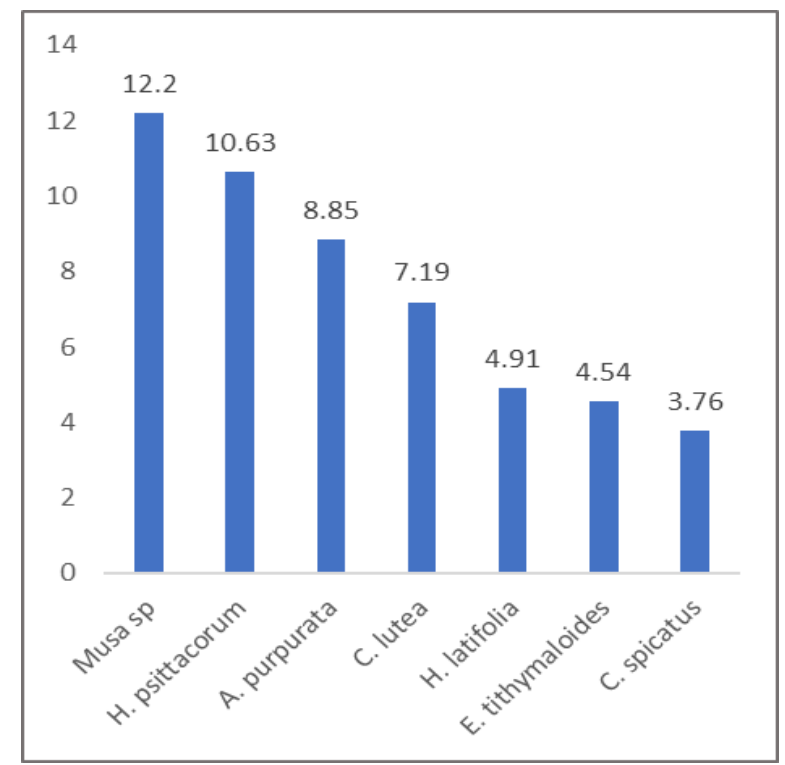

Fig. 2: $\mathrm{CO}_{2}$ Graph showing absorption by species of herbaceous plants

\section{Conclusion}

Total biomass accumulation and $\mathrm{CO}_{2}$ sequestered by all the herbaceous plants was $0.13 \mathrm{~kg}$ and $56.2 \mu \mathrm{mol} \mathrm{m}^{-2} \mathrm{~s}^{-1}$. Therefore, species of herbaceous plants like Musa sp, C. lutea and H. latifolia that sequestered $\mathrm{CO}_{2}$ better when compared to other species could be recommended for planting on the university campus for better sequestration and assimilation of carbon dioxide from the atmosphere.

\section{References}

[1] Abddullah, DMKB (2017) Carbon Emission Report University Tun Hussien Onn Malaysia: Universiti Tun Hussien Onn Malaysia.: Carbon Emission Report Unit.

[2] Armecin R \& Coseco W (2012), Abaca (Musa textilis Nee). Allometry for above-ground biomass and fibre production. Biomass and Bioenergy 46, 181-189.

[3] Bhalawe S, Jadeja D, Tandel M, Gayakvad P, Parmar M, Prajapati V, \& Behera L (2015), Non-Destructive Approach for Biomass Estimation and Carbon Mitigation in Different Land Use Systems. Trends in Biosciences 8(15), 3785-3790.

[4] Elliott KJ \& Clinton BD (1993), Equations for estimating biomass of herbaceous and woody vegetation in early-successional. Southern Appalachian pine-hardwood. Forests 365: US Department. of Agriculture and Forest Service. South-eastern Forest Experiment Station.

[5] Gedefaw M, Soromessa T \& Belliethathan S (2014), Forest carbon stocks in woody plants of Tara Gedam forest: Implication for climate change mitigation. Science, Technology and Arts Research Journal 3(1), 101-107.

[6] Gore A (2014), The Turning Point: New Hope for the Climate. Rolling Stone.

[7] Janine EV, Marinda LF, Shirley JS \& Marthina M (2004), The Southern African Herbarium User Manual.

[8] Joeri R, Michel DE, Niklas H, Taryn F, Hanna F, Harald W, Roberto S, Fu S, Keywan R \& Malte M (2016), Paris Agreement climate proposals need a boost to keep warming well below $2{ }^{\circ} \mathrm{C}$. $\mathrm{Na}$ ture (534), 631-639.

[9] Kumar BM (2011), Species richness and aboveground carbon stocks in the home gardens of central Kerala India. Agriculture, Ecosystems \& Environment 140(3), 430-440.

[10] NOAA (2012) \& Rajput SS (1985) National Oceanic and Atmospheric Administration. Journal of Timber Development Association of India 31(3), 12-41.

[11] Peacock TR (1992), The preparation of plant material and determination of weight per cent ash. US Dept. of the Interior, Geological Survey. 